\title{
Jesenov glivični rak v Črnem logu (Neonectria galligena)
}

\section{Nikica OGRIS $^{1^{*}}$, Dušan JURC ${ }^{1}$, Drago TRAJBER ${ }^{2}$}

V Črnem logu v Prekmurju smo spomladi 2009 opazovali sestoj velikega jesena (Fraxinus excelsior L.) s številnimi rakavimi poškodbami. Na skorji velikega jesena so bile različno velike nabrekline (hipertrofije), skorja je bila razpokana, na osrednjem delu nabrekline je skorja že odpadla in pod njo je bil opazen rjav do črn les, ki je imel rahlo vdolbino v sredini (slika 1). Ko smo skorjo odstranili, smo opazili rakaste rane velike do $30 \mathrm{~cm}$, ki so imele enakomerno, skoraj simetrično ovalno obliko (slika 2). Enakomerna simetrična oblika jesenovega raka je posledica dolgotrajne skupne rasti drevesa in glive. Drevo poskuša rano zarasti z oblikovanjem novega lesa in skorje $v$ vegetacijski dobi, vendar gliva preraste in uniči vsakoletno zarast pozimi, v času mirovanja vegetacije in rano tako poveča.

Povzročiteljico jesenovega raka v Črnem logu smo ugotovili s pomočjo izolacij gliv v čisto kulturo. Tri tedne po izolaciji smo z mikroskopom v kulturah nekaterih od izoliranih gliv opazovali hialine konidije z 1-3 prečnimi stenami (septami) (slika 3). Konidiji so merili 43,5-60,2 $(52,4) \times 5,2-6,7(5,8) \mu \mathrm{m}$. Opisane mikroskopske lastnosti čiste kulture glive ustrezajo glivi Neonectria galligena (Bres.) Rossman \& Samuels (neveljavno ime je Nectria galligena Bres.), t. j. glivi povzročiteljici jesenovega glivičnega raka. $N$. galligena je zelo razširjena zaprtotrosnica, ki kuži poleg jesenov še javor, brezo, topol, divji kostanj, vrbe, predvsem pa jablane in na njih povzroča nastanek rakov. Najenostavneje jo prepoznamo po spolnih trosiščih (peritecijih), ki so najprej živo rdeče barve, nato pa potemnijo, in se oblikujejo na robu rakavih ran najpogosteje jeseni. S prostim očesom opazni periteciji, iz katerih bruhajo dvocelične hialine (brezbarvne) askospore, se oblikujejo posamično ali v skupinah in imajo premer $0,25-0,35$ $\mathrm{mm}$. Peritecijev na skorji jesena v Črnem logu nismo našli.

Jesenov glivični rak lahko zamenjamo s jesenovim bakterijskim rakom ali poškodbami zaradi pisanega jesenovega ličarja:

- Jesenov glivični rak se od jesenovega bakterijskega raka, ki ga povzroča bakterija Pseudomonas syringae subsp. savastanoi pv. fraxini Janse /Br./ Dow., razliku- je po tem, da gliva povzroča rake, ki so skoraj pravilne simetrične oblike, bakterija pa rake nepravilne oblike (npr. bradavičasti tip zaprtega raka ali odprti rak nepravilne, zverižene oblike).

- Poškodbe, ki jih povzroča pisan jesenov ličar (Leperesinus fraxini Panzer), prepoznamo po značilnih "jesenovih rožah". Na terenu lahko ugotovimo vzrok za poškodbe tako, da skozi "jesenovo rožo" zarežemo z nožem. V notranjosti bradavičaste hipertrofije opazimo rove pisanega jesenovega ličarja. $\mathrm{V}$ teh hipertrofijah hrošček prezimuje.

Prisotnost jesenovega glivičnega raka pomeni, da ima gliva povzročiteljica raka $\mathrm{v}$ pregledanih sestojih ugodne razmere za okužbo in razvoj. Z dolgoletnim razvojem rakov na jesenih se skozi odprte rane lahko naselijo glive razgrajevalke lesa in dodatno poškodujejo in razvrednotijo jedrovino debla. Zato je ustrezno, da drevesa $z$ raki odstranimo iz sestoja. Poleg tega je priporočljivo zmanjšati delež jesena $\mathrm{v}$ sestojih, saj se $\mathrm{Z}$ oddaljenostjo od okuženega drevesa zmanjša možnost okužbe zdravih jesenov.

\section{Viri}

Booth C. 1959. Studies of Pyrenomycetes: IV. Nectria (Part I). Mycological Papers, 73: 115 str.

Dennis R.W.G. 1978. British Ascomycetes. Vaduz, J. Cramer: 585 str.

Jurc M. 2008. Gozdna zoologija. Ljubljana, Univerza v Ljubljani, Biotehniška fakulteta, Oddelek za gozdarstvo in obnovljive gozdne vire: 348 str.

Maček J. 2008. Gozdna fitopatologija. Ljubljana, Zavod za gozdove Slovenije, Zveza gozdarskih društev Slovenije - Gozdarska založba: 448 str.

Rossman A.Y., Samuels G.J., Rogerson C.T., Rosalind L. 1999. Genera of Bionectriaceae, Hypocreaceae and Nectriaceae (Hypocreales, Ascomycetes). Studies in Mycology, 42: 248 str.

${ }^{1}$ Gozdarski inštitut Slovenije, Večna pot 2, 1000 Ljubljana; ${ }^{2 Z a v o d ~ z a ~ g o z d o-~}$ ve Slovenije, Območna enota Murska Sobota, Arhitekta Novaka 17, 9000 Murska Sobota *nikica.ogris@gozdis.si 


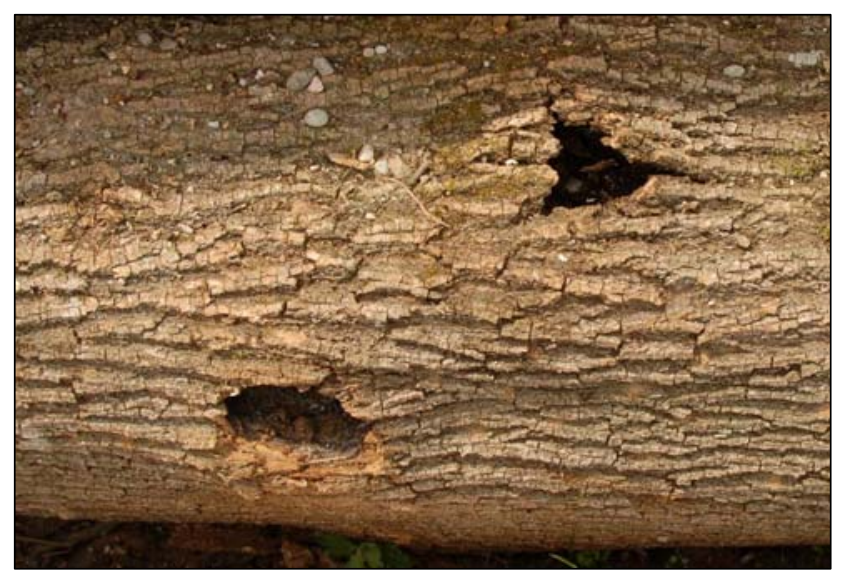

Slika 1: Jesenov glivični rak na velikem jesenu, rahlo privzdignjena skorja, skorja je razpokana $\mathrm{z}$ odprtino na sredini

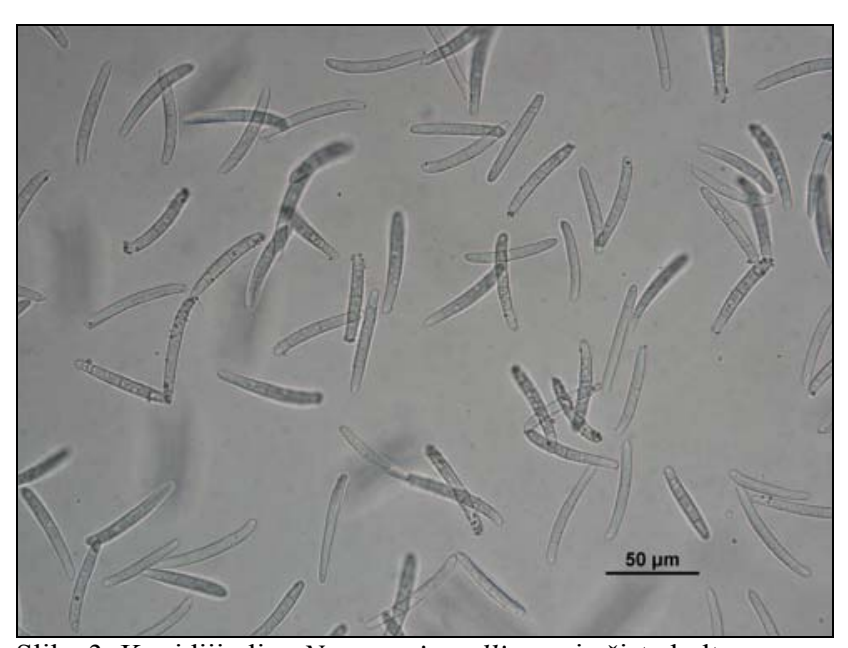

Slika 3: Konidiji glive Neonectria galligena iz čiste kulture

3: Konidiji glive Neonectria galligena iz čiste kulture

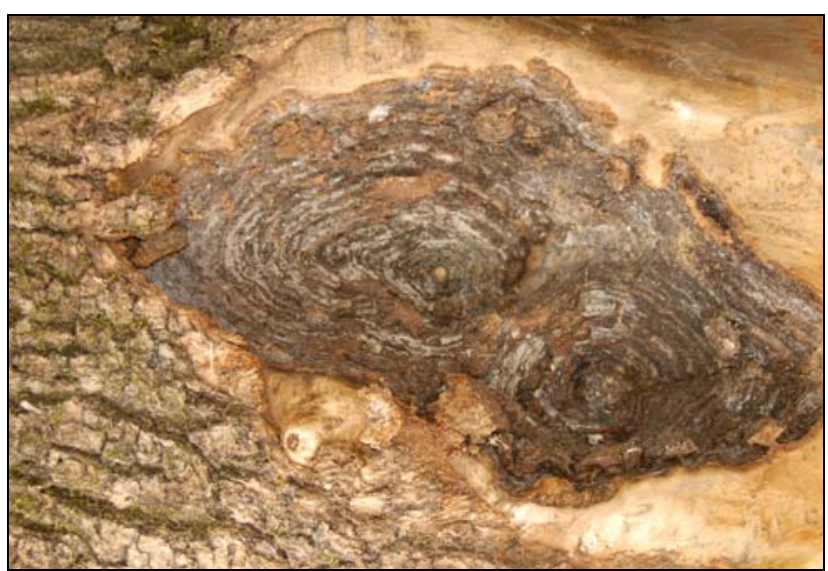

Slika 2: Pod skorjo je rak skoraj pravilne simetrične oblike

\section{Posledice toče na gozdnem in okrasnem drevju v okolici Ptuja zaradi neurja avgusta 2008}

\section{Nenad ZAGORAC}

Nevihta z močnim vetrom in zelo debelo točo (tudi velikosti kokošjega jajca) je v večernih urah 15 . avgusta 2008 zajela področje od mesta Ptuja preko Destrnika do Trnovske vasi v širini 5-10 km. Debela toča je poškodovala gozdove na površini okrog 2000 ha. Na gozdnem drevju je bilo po ocenah krajevnih gozdarjev poškodovanih 20 do $100 \%$ listja in iglic, tako da so določeni gozdovi bili videti kot jeseni (slika 1). Zanimiv je bil pojav na hrastih, ki so v septembru 2008 ponovno olistali in so bili zeleni v november do prvega mraza.

Posledice nastale škode so dobro vidne šele v letošnjem letu. V gozdovih so najmočneje prizadeta drevesa rdečega bora, ki marsikje niso ali ne bodo preživela, saj je bilo uničenih preveč iglic(slika 2). Močno poškodovana so okrasna drevesa zunaj gozda, ki niso imela zaščite sosednjih dreves (slika 3).Posledice na listavcih bodo vidne šele $\mathrm{v}$ naslednjih letih, saj poškodbe na poganjkih bistveno povečujejo možnost za razvoj bolezni in napada škodljivcev (slika 4).

Zavod za gozdove Slovenije, Območna enota Maribor, Tyrševa 15, 2000 Maribor

*nenad.zagorac@zgs.gov.si 